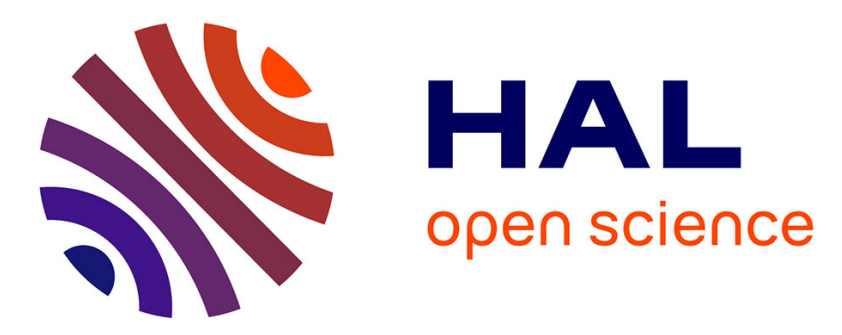

\title{
Selecting a Notation to Modeling Business Process: A Systematic Literature Review of Technics and Tools
}

\author{
Marcelo Bernardino Araújo, Rodrigo Franco Gonçalves
}

\section{To cite this version:}

Marcelo Bernardino Araújo, Rodrigo Franco Gonçalves. Selecting a Notation to Modeling Business Process: A Systematic Literature Review of Technics and Tools. IFIP International Conference on Advances in Production Management Systems (APMS), Sep 2016, Iguassu Falls, Brazil. pp.198-205, 10.1007/978-3-319-51133-7_24. hal-01615808

\section{HAL Id: hal-01615808 \\ https://hal.inria.fr/hal-01615808}

Submitted on 12 Oct 2017

HAL is a multi-disciplinary open access archive for the deposit and dissemination of scientific research documents, whether they are published or not. The documents may come from teaching and research institutions in France or abroad, or from public or private research centers.
L'archive ouverte pluridisciplinaire HAL, est destinée au dépôt et à la diffusion de documents scientifiques de niveau recherche, publiés ou non, émanant des établissements d'enseignement et de recherche français ou étrangers, des laboratoires publics ou privés. 


\title{
Selecting a Notation to Modeling Business Process: a Systematic Literature Review of Technics and Tools
}

\author{
Marcelo Bernardino Araújo ${ }^{1,2}$ and Rodrigo Franco Gonçalves ${ }^{1}$ \\ 1 Paulista University, São Paulo, Brazil \\ \{mbernardinos, rofranco212\}@gmail.com \\ 2 Federal Institute of Education, Science and Technology, São Paulo, Brazil
}

\begin{abstract}
There are several different notations available in the market to business process modeling. An adequate business process model tool allows the understanding regarding the several operational flows inside an organization. This article has two objectives: first, to identify and to compare alternative business process modeling notations; second, to select an adequate notation to be applied in the modeling the business process of accounting system to higher education entities. Then, a literature review was carried out, including a rigorous research in indexed database. We also tested the available tools based on BPM model. Among the studied notations the BPMN was selected since it demonstrated to be the more adequate notation for complex processes once it contains a wide variety of symbols, which are easily comprehended.
\end{abstract}

Keywords: Layout $\cdot$ BPM $\cdot$ Costing Systems $\cdot$ Modeling $\cdot$ Process

\section{Introduction}

Modeling and mapping a business helps the reduction of superfluous activities inside an organization. Both globalization and competitiveness in some sectors may lead companies to review their profit margins as well as their expenses. Optimization, i.e. the intense processes review, makes an organization more efficient, helping to increase both products and services quality and in some cases it also permits the reduction of the environmental impact [1].

Nowadays, there are several notations to represent a process, as for example: Business Process Management Notation (BPMN), Event-Driven Process Chain (EPC), Flowchart, Integrated Computer Aided Manufacturing DEFinition for Function Modeling (IDEF0), Unified Modeling Language - Activity (UML) and Value Stream Mapping (VSM). Choosing an notation contributes to the success of implementing an information system to manage the business [2]. But, among the diversity of available notations to represent and model a business, which one should we select?

The present article aims to identify an adequate notation to model the necessary processes to develop an accounting system applied to higher education 
entities, since there is a global awareness regarding the expenditures of the universities [3].

In the following sections, we present a literature review of the main points to be addressed, detail the research performed, present observations regarding the response and the choice of a notation based on the literature and software tests to develop a costing system, and finally formulate the final observations that may be used to prepare a business model based on BPM.

\section{Literature Review}

Inside the organizations, several processes and procedures are created, reviewed and finalized every day. Process and procedure may be similar words, but they must be utilized correctly [4].

While a procedure describes how a task is performed in detail and how it fits in a process, regarding how and who execute the task, i.e. a procedure details the technical requirements of a task about a process [4], a process represents the aggregation of activities and behaviors executed by humans or machineries to achieve one or more results [5]. A process describes a sequence of activities carried out from the beginning until the end aiming to produce a result to the client, emphasizing the activity and its conduction [4].

The Figure 1 represents the flow of a process and how its elements interact. Each process has its specific monitoring and measurement indicators necessary to its control. The formalization of a process is necessary to create either a product or a service, since it depends of inputs, several steps and procedures to fabricate a final product $[5,6]$.

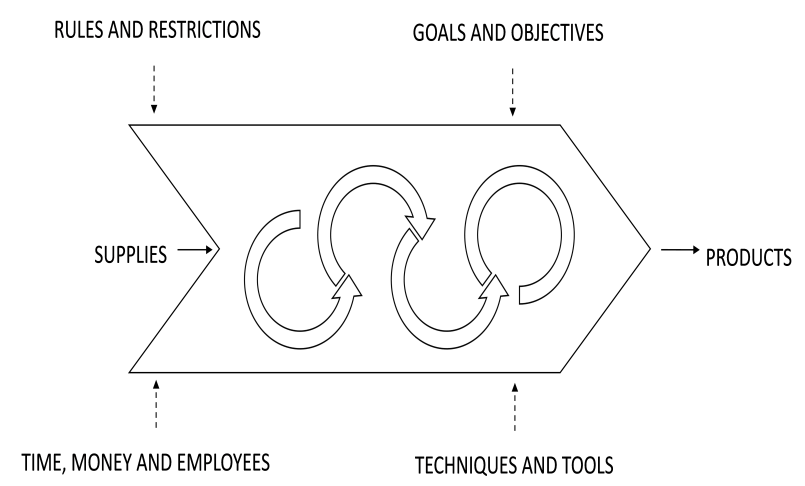

Fig. 1. Representation of the elements in a process

A notation is defined by a set of standard, symbols and rules that determine their meaning [5]. These representations support visually the understanding of 
a process, either simple or complex, and it can be understand more efficiently due to an adequate notation.

\subsection{Mapping and Modeling Processes}

A diagrammatic representation aims to simplify the understanding about several aspects of a process, since symbols can represent several contexts. In this sense, for a better comprehension of a process, standard notations constitute a set of knowledge due to their documentation $[7,8]$.

The mapping process of an organization is the knowledge and the analysis of its processes and data interconnection, and it is structured in a top-down design (from the top of the organization to the base), to a level that allows a thorough comprehension of products, services and results [4].

It implies more precision when compared to a flow representation and it may aggregate more detail regarding, not only to the process, but also the relationship among several elements, such as stakeholders, events and results. A process map typically provides an overview about the main components of a process, but it may change from higher to lower levels of detail [5].

On the other hand, business process model is the set of activities regarding the representation of the current or a proposed process. It may provide a sideto-side perspective or a part of a primary process regarding to either support or management [5]. The process modeling is applied to represent graphically the current or a future process inside the organization [6].

While the mapping process regards to a current and non-documented process, and the modeling is applied to the development of new processes and procedures.

\subsection{Business Process Management}

The BPM is a management discipline that integrates strategies and objectives of an organization with customer expectations and needs, by focusing on processes, end to end. This methodology encompasses strategies, objectives, culture, organizational structures, roles, policies, methods and technologies to analyze, design, implement, manage performance, process and establish governance processes [5]. It is based on two pillars:

The first one regards on the studies $[9,10]$ about statistical control of process that originates the current quality management represented by Six-Sigma.

The second one is related to business reengineering process [11,12] and it has interdependent positive and negative aspects. The reengineering was initially introduced not as a continuous improvement process, but as an occasional initiative.

The application of the BPM as a management method for business process, which involve several technologies such as online tools, cloud computing, is a competitive advantage and it also supports changes as: marketing, new technologies, IT infrastructure and both clients and suppliers necessities [7]. 


\section{$2.3 \quad$ ISO, BPM CBOK and BABOK}

The standardization of procedures has becoming usual mainly due to a globalized environmental [7]. There is three basic tools when applied together provide a support to build a process: ISO 9000, Business Process Management Common Body of Knowledge (BPM and CBOK) and Business Analysis Body of Knowledge (BABOK). A Body of Knowledge (BOK) is a practical guide for professionals that constitute the source of knowledge for most of professional curriculums. Its content represents the basic competences required for the professionals before their accreditation [7].

The International Organization for Standardization (ISO) was created in 1947 to promote normalization of products and services due to a continuous improvement ideology. Among several publications, the ISO 9000 series of standards concerns about quality management. The process approach [13] allows the management of the organization due to processes interaction. Several enterprises around the world search for the ISO certification [13], since the ISO 9000 conformity certification introduces credibility to the organization.

In order to avoid interference between the process and business analysts, they both have to understand the organization's necessities. The expertise of these professional can be attested by certification. The Association of Business Process Management Professionals (ABPMP) certifies the professionals due to the CBPP examination (Certified Business Process Professional) which demands a sound knowledge of the BPM CBOK procedures [5].

Moreover, two certifications are available by the International Institute of Business: CBAP (Certified Business Analysis Professional) for junior and CCBA (Certificate of Competency in Business Analysis) for senior level professionals. However, a thorough expertise of the BABOK is required [6].

\section{Methodology}

We carried out a systematic literature review to select the more appropriate modeling technic to develop an accounting system, once a peer review is a typical indicator for quality, since it is based on direct expertise of the reviewers and their knowledge [14]. A systematic literature review process has also been shown to be an appropriate tool to manage and organize the growing number of databases for articles, allowing the identification of relevant contributions.

The selected electronic databases where the searches were conducted from January to March 2016 are showed in Table 1. A 10-year time limit for sample studies was set in order to incorporate only recent studies. The searches were conducted using the following string: "business process modeling" AND ("costing system" OR "cost accounting").

After the systematic search in the databases, we selected the studies that only satisfy the objective of choosing a modeling process method. Additionally, we tested various free source modeling tools in order to verify which one would model precisely a complex processes as the ones in public sectors, since our goal 
is to develop a Time-Driven Activity Based Costing to the Federal Institution of Science and Technology of São Paulo. For the process modeling we used the soft-

Table 1. Electronic databases consulted

\begin{tabular}{cc}
\hline Name & Results \\
\hline ASCE Library & 4,074 \\
DOAJ & 2 \\
EBSCO host & 3 \\
IEEE Xplore & 109 \\
ProQuest & 1 \\
ScienceDirect & 155,94 \\
Scopus & 7 \\
Web of Science & 1 \\
Wiley Online Library & 176,06 \\
\hline
\end{tabular}

ware Yaoqiang BPMN Editor 4.0.42 [15], and Microsoft Visio 2010 to flowchart and UML - Activity [16]. These software allowed us to model using both BPMN, UML and flowchart concepts. Moreover, the flowcharts are tools constantly applied in patents [17]. In addition, we tested the open software named StarUML 5.0.2.1570.

The Based Knowledge Systems Incorporation (KBSI) maintains a paid version of the IDEF0 notation software, which is based on the Activity-Based Costing $(\mathrm{ABC})$ method [18], however we did not tested the notation.

For EPC and VSM we applied the SmartDraw that can be used either in desktop or cloud version, which choice we based on expertise [19]. This software is a viable alternative for the Microsoft Visio once it is available freely and contemplates diverse notations as well as schemas, plots, flowcharts and BPMN.

\section{Results and Discussion}

The use of flowcharts is designed for users who use little information systems. The survey noted the recommendation to use BPMN in $[2,16,20]$. However, to perform the mapping and modeling processes properly, the business analyst to analyze the business requirements be careful when making the drawings, because the tasks are below the level of activities [4].

Among the notations on the market, the most known and used were analyzed in this research. The characteristics of each are shown in Table 2.

After the systematic process of reviewing the literature and consulted and analyzed nine studies, two professional guides and a book relevant to the process of choosing the appropriate notation for modeling business processes, we reached the result shown in Figure 2.

After the analysis of the results, select the BPMN notation, because the advantages outweigh the disadvantages. Its main advantages are: ease of use, 
Table 2. Notations for process modeling

\begin{tabular}{|c|c|}
\hline Notation & Description \\
\hline BPMN & $\begin{array}{l}\text { It is useful to represent a model to Object Management Group } \\
\text { different target audience. }\end{array}$ \\
\hline Flowchart & $\begin{array}{l}\text { It facilitates the understanding of a } \\
\text { process flow, however the symbols } \text { Standards Institute (ANSI) } \\
\text { are not standardized. }\end{array}$ \\
\hline $\mathrm{EPC}$ & $\begin{array}{ll}\text { It is useful to model complex sets } & \begin{array}{l}\text { Institut für Wirtschaftsin- } \\
\text { formatik Universität des } \\
\text { of processes. }\end{array} \\
\text { Saarlandes }\end{array}$ \\
\hline IDEF0 & $\begin{array}{l}\text { It uses a systemic view highlight- } \\
\text { ing inputs, outputs, control mech- } \\
\text { anisms, processes control and rela- (USAF) } \\
\text { tion between lower and higher lev- } \\
\text { els. }\end{array}$ \\
\hline UML Activity & $\begin{array}{l}\text { It is a diagramming technique ori- } \text { Object Management Group } \\
\text { ented to describe the requirements } \\
\text { of an information system. }\end{array}$ \\
\hline $\begin{array}{l}\text { Value Stream } \\
\text { Mapping }\end{array}$ & $\begin{array}{l}\text { It shows the efficiency of processes } \\
\text { mapping the use of resources and Toyota Motor } \\
\text { time variables. }\end{array}$ \\
\hline
\end{tabular}

\begin{tabular}{|c|c|c|c|c|c|c|}
\hline Features / Notations & $\sum_{\frac{\lambda}{M}}^{z}$ & 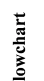 & 产 & $\begin{array}{l}\text { 是 } \\
\text { 䆓 }\end{array}$ & 光良 & $\sum_{\substack{n \\
>}}^{\Sigma}$ \\
\hline \multicolumn{7}{|c|}{ Advantages } \\
\hline Use and understanding spread & $\mathrm{x}$ & & $\mathrm{x}$ & & $\mathrm{X}$ & \\
\hline Fast learning & & $\mathrm{x}$ & & & & $\mathrm{X}$ \\
\hline Versatility in modeling & $\mathrm{x}$ & & $\mathrm{x}$ & & & \\
\hline Describes complex processes & $\mathrm{x}$ & & & $\mathrm{x}$ & & \\
\hline Supported by other tools & $\mathrm{x}$ & $\mathrm{x}$ & & & $\mathrm{x}$ & \\
\hline \multicolumn{7}{|c|}{ Disadvantages } \\
\hline It requires experience for using the symbology & $\mathrm{x}$ & & $\mathrm{x}$ & $\mathrm{x}$ & $\mathrm{x}$ & \\
\hline There are many variations on the symbology & & $\mathrm{x}$ & & $\mathrm{x}$ & & $\mathrm{x}$ \\
\hline Difficulty in viewing between levels & $\mathrm{x}$ & & $\mathrm{x}$ & $\mathrm{x}$ & $\mathrm{x}$ & $\mathrm{x}$ \\
\hline It does not describe complex procedures & & $\mathrm{x}$ & & & $\mathrm{x}$ & $\mathrm{x}$ \\
\hline May require different tools for use & $\mathrm{x}$ & & & & $\mathrm{x}$ & \\
\hline
\end{tabular}

Fig. 2. Qualitative comparison of the notations

versatility, supported by other tools and mainly describe complex processes. The main drawback in using BPMN is a wide variety of symbols, therefore, the user requires a certain level of knowledge and proper use. In other notations, 
only IDEF0 is also capable of describing complex processes. This notation is recommended by [20].

\section{Conclusions}

The realized comparison of the business process notations allows the selection BPMN as the most adequate notation to map and model processes to the accounting system. This process requires a communication without noise from the Process Analyst and Business Analyst with a view to developing an IT solution. The main advantage of BPMN is that he is able to describe complex processes. However, it has the disadvantage of a great variety of symbols, but understandable.

A costing system will be developed to the Federal Institute of Education, Science and Technology of São Paulo - IFSP based on process modeling using a BPMN notation.

\section{Acknowledgment}

The authors would like to thank CAPES (Coordenação de Aperfeiçoamento de Pessoal de Nível Superior) and IFSP (Instituto Federal de Educação, Ciência e Tecnologia de São Paulo) for the financial support to develop this work.

\section{References}

1. Chompu-inwai, R., Jaimjit, B., Premsuriyanunt, P.: A combination of Material Flow Cost Accounting and Design of Experiments Techniques in an SME: The Case of a Wood Products Manufacturing Company in Northern Thailand. Journal of Cleaner Production 108, 1352-1364 (2015)

2. Thiemich, C., Puhlmann, F.: An Agile BPM Project Methodology. In: Daniel, F., Wang, J., Weber, B. (eds.) Business Process Management, vol. 8094, pp. 291-306. Springer Berlin Heidelberg, Berlin, Heidelberg (2013)

3. Araújo, B, M., Gonçalves, R.: Costing Systems for use in Public Universities: The Brazilian and International Context. International Journal of Education and Research 2(12), 1-12 (2014)

4. Stoneham, R.: Innovating Business Processes for Profit: How to Run a Process Program for Business Leaders. Balboa Press (2015)

5. V3.0, A.B.C.: Guide to Business Process Management Body of Knowledge - Common Body of Knowledge. Association of Business Process Management Professionals - ABPMP (2013)

6. IIBA: A Guide to the Business Analysis Body of Knowledge (BABOK Guide), Version 2.0. International Institute of Business Analysis (2009)

7. Bandara, W., Harmon, P., Rosemann, M.: Professionalizing Business Process Management: Towards a Body of Knowledge for BPM. In: van der Aalst, W., Mylopoulos, J., Sadeh, N.M., Shaw, M.J., Szyperski, C., zur Muehlen, M., Su, J. (eds.) Business Process Management Workshops, vol. 66, pp. 759-774. Springer Berlin Heidelberg, Berlin, Heidelberg (2011) 
8. Milani, F., Dumas, M., Ahmed, N., Matulevičius, R.: Modelling Families of Business Process Variants: A Decomposition Driven Method. Information Systems 56, $55-72(2016)$

9. Deming, W.E.: Elementary Principles of the Statistical Control of Quality: A Series of Lectures. Nippon Kagaku Gijutsu Remmei (1952)

10. Shewhart, W.A., Deming, W.E.: Statistical Method from the Viewpoint of Quality Control. Courier Corporation, New York (1939)

11. Hammer, M.: Reengineering Work: Don't Automate, Obliterate. Harvard business review 68(4), 104-112 (1990)

12. Hammer, M., Champy, J.: Reengineering the Corporation: A Manifesto for Business Revolution. Harper Business, New York (1993)

13. Terziovski, M., Guerrero, J.L.: ISO 9000 Quality System Certification and its Impact on Product and Process Innovation Performance. International Journal of Production Economics 158, 197-207 (2014)

14. Brinn, T., Jones, M.J., Pendlebury, M.: Measuring research quality: peer review 1, citation indices 0. Omega 28(2), 237-239 (2000)

15. Geiger, M., Wirtz, G., Weberei, A.: BPMN 2.0 Serialization - Standard Compliance Issues and Evaluation of Modeling Tools. EMISA pp. 177-190 (2013)

16. Fu, L., Kara, L.B.: From engineering diagrams to engineering models: Visual recognition and applications. Computer-Aided Design 43(3), 278-292 (2011)

17. Ramesh, A., Covert, P., Rhodes, S., Hunter, S., Vian, J., Wilmering, T.: Method and system for evaluating costs of various design and maintenance approaches. Google Patents (2006), https://www.google.com/patents/US20060089920, uS Patent App. 10/972,916

18. Tatsiopoulos, I., Panayiotou, N.: The integration of activity based costing and enterprise modeling for reengineering purposes. International Journal of Production Economics 66(1), 33-44 (2000)

19. Davies, I., Reeves, M.: BPM Tool Selection: The Case of the Queensland Court of Justice. In: Brocke, J.v., Rosemann, M. (eds.) Handbook on Business Process Management 1: Introduction, Methods, and Information Systems, pp. 371-392. Springer Berlin Heidelberg, Berlin, Heidelberg (2015)

20. Trehan, V., Chapman, C., Raju, P.: Informal and formal modelling of engineering processes for design automation using knowledge based engineering. Journal of Zhejiang University Sciencie A 16(9), 706-723 (2015) 